\title{
CONCEPTUALIZING MOBILE DIGITAL LITERACY SKILLS FOR EDUCATORS
}

\author{
Farshida Jahoor $^{1}$, Adele Botha ${ }^{2}$ and Marlien Herselman ${ }^{2}$ \\ ${ }^{1}$ University of South Africa, Preller St, Muckleneuk, Pretoria, South Africa \\ ${ }^{2}$ CSIR, University of South Africa, Meiring Naudé Road, Brummeria, Pretoria, South Africa
}

\begin{abstract}
With mobile phones as a near pervasive technology amongst the youth, their use in classroom practice are often considered particularly daunting by the teaching fraternity. Many teachers qualified in the so-called 'pre PC' era, and do not consider themselves on technology par with their students. Their students on the other hand are growing up in an era of technology immersion. In order to enact the 'loco parentis' role often required, these educators need to be equipped with mobile digital literacy skills; often neglected in, amongst other, Teacher Professional Development interventions. The purpose of this paper is conceptualize mobile digital literacy skills for educators in using mobile technology in formal education. The research exapts the 'best-fit' framework synthesis of Carroll et al. (2013) from the health domain, towards this end. The strategy is operationalized through two phases. Phase 1 identifies the $\mathrm{Ng}(2013)$ digital skills model as a priory framework. Phase 2 utilizes the categories presented in Phase 1 to guide the classing of purposefully selected literature towards conceptualizing mobile digital literacy skills for educators using mobile technology in formal education. The literature considered was identified in accordance with Grant et al. (2014) description of a systematized scoping review. The contribution of this paper lies in its outcomes to identify and classify literacy skills for mobile technologies. These identified skills can further guide interventions aimed at educational mobile phone use.
\end{abstract}

\section{KEYWORDS}

Mobile Digital Literacy Skills, Mobile Devices, Literacy, Digital Literacy

\section{INTRODUCTION}

The number of mobile technology users have increased considerably, not only South Africa, but across the world (ITU, 2018), making mobile ICT the world's fastest growing technology. The perceived availability of the technology and the established user base present several developmental opportunities (Van Biljon \& Renaud, 2017). As mobile Information and Communication Technology (ICT) continues to permeate the market (Chang \& Hwang, 2018), the ability to navigate the technology becomes even more important (Bartikowski, Laroche, Jamal, \& Yang, 2018). This state of affairs has created a conundrum within the education domain in South Africa (Mabila, Biljon, \& Herselman, 2017) where educators are supplied with technology, that they are expected to meaningfully utilize in their classroom practice, in support of 21st century teaching and learning (Finn-Stevenson, 2018). However, ICT education initiatives have been noted to have failed due to a lack of a focus on, amongst other factors, the digital literacy skills (Mabila et al., 2017). The lack of skills pose a challenge for educators to successfully integrate mobile technologies into classrooms (Yu, Lin, \& Liao, 2017).

This paper endeavors to conceptualize mobile digital literacy skills towards eventually enabling the articulation of the mobile digital literacy skills needed by educators using mobile technologies in formal education. The perspective of formal education highlights the active teaching and learning activities that are associated with classroom practice. As such, this paper prioritizes specific instances where mobile technology is used in educational specific contexts, although not necessarily as an exclusive focus to answer the research question: What constitutes mobile digital literacy skills for educators in formal education? 


\section{METHOD}

This paper adopts the 'best-fit' framework synthesis of Carroll, Booth, Leaviss, and Rick (2013) towards conceptualizing mobile digital literacy skills for educators when embarking on using mobile technology in their classroom practices. The technique presents a method to extend on existing published research artifacts, in the form of models frameworks or theories, conceived within sufficiently similar context. The 'best fit' framework synthesis is considered suitable for this study as it entails a moderately rapid, transparent and pragmatic process whereby purposefully selected literature can be scrutinized at the hand of a priory research artifact. The systematic method for identifying suitable frameworks and subsequent thematic analysis enables both artifact and literature synthesis outcomes that are "reproducible and correspond to a shared reality" (Carroll et al., 2013, p. 1). This paper enacts the best-fit framework synthesis through the identification of a suitable digital literacy model as a relevant research artifact that can be abstracted to themes, which forms the a priori framework for a systematized scoping review as outlined by Grant and Booth (2009). A systematized scoping review is envisioned to cover the breath of the literature available while providing a systematic, transparent method in its identification and selection.

The methodology followed in this paper is then operationalised in two phases. Firstly, a literature synthesis that involves the identification of a priori themes against which to map literature from purposefully selected studies in the second phase. The identification and selection of a priori framework that would present the themes is outlined in section 3, the thematic synthesis at the hand of the themes is detailed in section 4. Due publication constraint, a full literature overview is not feasible and only a literature synthesis is presented in both section 3 and 4 .

\section{A PRIORY FRAMEWORK}

In selecting a suitable framework, relevant and well-cited articles documenting research artifacts such as frameworks, models and theories for mobile digital literacy skills were sought in academic journals, as indicated in Table 1. As per year of publication, articles from 2000 to 2018 were included. Some older articles were incorporated as they were highly cited by other publishing researchers or were often viewed.

Table 1. Identifying a priory framework

\begin{tabular}{l|l}
\hline & Systematised scoping review to select a priory framework \\
\hline Keywords & Digital, Literacy, Digital skills, Framework \\
Literature review method & Systematized Scoping \\
Databases used & Scopus, IEEE Xplore, Wiley Online Library, Web of Science, Science Direct \\
Inclusion and exclusion & Only publications written in English were used; Studies referring to the components of \\
principles & digital skills were used; Studies including frameworks and models of digital skills were \\
Number of papers used & 30 \\
\hline
\end{tabular}

The literature suggests that reading and writing were adequate literacy proficiencies a few decades ago and certainly sufficient to distinguish the educated in society (Zheng, Yim, \& Warschauer, 2018). Lankshear and Knobel (2008) argue that this, however, is no longer the case. Technology has given rise to new literacies, involving different sets of skills and abilities to perceive and manage information. Markauskaite (2007) further notes that practical skills are a very important aspect of digital literacy. At the same time these is consensus that the notion of digital literacy refers to more than the mere operation of a technological device (Parry, Eikhof, Barnes, \& Kispeter, 2018; Sadaf \& Johnson, 2017; Zapata, 2018; Zheng et al., 2018).

Several approaches have been used to unpack the idea of digital literacy. Some authors regard digital literacy as a group of literacies (Eshet-Alkalai, 2004; Eshet-alkalai \& Chajut, 2009; Jisc, 2015; Parry et al., 2018; Sadaf \& Johnson, 2017; Zapata, 2018; Zheng et al., 2018), while others are proponents of a component view of digital literacy (Ferrari, 2008; Gilster, 1997; Schreuers, Quan-Haase, \& Martin, 2017). This research identified the digital literacy model of $\mathrm{Ng}$ (2012) as the most appropriate as it manages to combine most of the published literacies and/or components into a single digital literacy model. The themes identified and their conceptual relations suggests that digital literacy is facilitated by the intersection of technical, cognitive and social-emotional perceptions. The three dimensions are briefly outline in Table 2. 
Table 2. A priory framework for educator digital skills ( $\mathrm{Ng}, 2012)$

\begin{tabular}{l|ll}
\hline Dimension & Literacy & Description \\
\hline Technical & Operational Literacy; Reproduction Literacy; Branching & Technical and functional expertise of \\
dimension & Literacy; Social networking functional literacy & ICT in daily use. \\
Cognitive & Information Literacy; Reproduction Literacy; Branching & Critical thinking for digital \\
dimension & Literacy; Online etiquette literacy; Cyber safety Literacy & information. \\
Social-emotional & Social-emotional literacy; Social networking functional & Use internet appropriately. \\
dimension & literacy; Online etiquette literacy; Cyber safety Literacy & \\
All dimensions & Critical Literacy & Applicable to all dimensions \\
\hline
\end{tabular}

$\mathrm{Ng}$ (2012) has argues that the dimensions of digital literacy are very much applicable to mobile devices. The digital literacy model of $\mathrm{Ng}$ (2012) is then selected as a scaffold against which the literature examined in the following section (section 4) can be brought together and organized.

\section{SYSTEMATISED SCOPING REVIEW}

The literature review scrutinized the phenomena of Mobile Information and Communication Technology (ICT), and ICT in the education domain as framed by the a priory framework themes outlined in Table 2.

Table 3. Summary of search criteria for literature review

\begin{tabular}{|c|c|}
\hline & Mobile Information and communication Technology (ICT) \\
\hline Keywords & $\begin{array}{l}\text { Mobile ICT, Connectivity, Networks, Adoption model, Mobile digital literacy } \\
\text { skills }\end{array}$ \\
\hline Literature review & Systematised Scoping \\
\hline Databases used & $\begin{array}{l}\text { Information systems research, INFORMS } \\
\text { journal of Computing and MIS Quarterly: Management Information systems, Web } \\
\text { of Science, Science Direct }\end{array}$ \\
\hline Inclusion and exclusion principles & $\begin{array}{l}\text { Only publications written in English were used; Studies referring to the } \\
\text { components of Mobile Digital Literacy skills were included; Studies looking at } \\
\text { mobile technology in Africa were considered; and Uptake of technology in } \\
\text { non-African rural areas were excluded. }\end{array}$ \\
\hline $\mathrm{N}^{\circ}$ of papers & 70 \\
\hline
\end{tabular}

The following narrative highlights some of the most relevant literature towards synthesizing a conceptualization of mobile digital literacy skills of educators using mobile technology formal education.

Mobile technologies have evolved over the years, from specific devices created for either communication or information access, to a powerful mixed device supporting both information access and communication (Chipangura, 2016; Walls, 2017). Mobile technologies are described as computing devices that are portable due to their smaller size (like a cell phone or smartphone) and can include tablets, laptops and netbooks (Valk, Rashid, \& Elder, 2010). Within this understanding, mobile digital literacy is seen as a subset of digital literacy. This view is supported by Hansen (2018) and $\mathrm{Ng}$ (2013). Digital literacy is described as progressive and adaptive and builds on initial skills which lead to the adaptation of new and emerging mobile devices requiring mobile digital literacy skills (Ng, 2012). Clark, Coward, Rothschild et al. (2017) agree and concede that the experience of using a mobile device differs to that of any other technological device. The European Information Society supplied a brief definition of mobile digital literacy skills as an individual's ability to use mobile devices to manipulate digital data and to interact (Martin, 2018). Despite the significant amount of research has been carried out on digital literacy and digital literacy skills, mobile digital literacy skills is yet to be comprehensively articulated (Hansen, 2018). Many of the published authors affirm that the available digital literacy frameworks have failed to incorporate a mobile-centric orientation (Clark et al., 2017; $\mathrm{Ng}, 2012$ ).

Van Biljon and Kotzé (2007) proposed a Mobile Phone Technology Adoption Model (MOPTAM) depicts the determining and mediating factors in mobile technology uptake and use. Van Biljon and Kotzé (2007) categorized the following six determining factors: Social influence, these conditions refer to the social burden placed on individuals, based on the opinions and beliefs of other people or groups. This category includes social influences and perceived usefulness and ease of use; Facilitating conditions refers to mobile phone infrastructure which comprises of: system services, cost of system services and cost of handset; Perceived 
usefulness as the degree to which an individual believes in the benefits of a mobile device; Perceived ease of use which is described as the degree to which an individual believes that using the device will be effortless; Attitude involves the negative or positive associations of an individual with a targeted behavior; and the behavioral intention, that involves perceived performance while interacting with a mobile device.

The three mediating factors that determine mobile phone usage, are (Van Biljon \& Kotzé, 2007): Personal factors that include an individual's personal preferences and/or beliefs regarding the benefits of technology. Therefore, relative advantage, compatibility, intricacy, image, trust and observability are considered; Demographic factors denoting an individual's age, gender, education level and technological expertise and ability; and the Socio-economic factors that include variables like job status, occupation and earnings.

Together these determining and mediating factors affect the actual usage of a device (Van Biljon \& Kotzé, 2007). Additionally it can be argued that improvements in mobile devices have led to a further increase in the number of users (Mushi, Jafari, \& Ennis, 2018). In support of this, Chipangura (2016) mentions that many South Africans prefer acquiring a more feature enabled smartphone which has resulted in a decreased demand for feature phones. The increase in smartphone usage could be due to two factors. Firstly, the increased broadband network coverage reaching more or less $90 \%$ of South Africa (Chipangura, 2016) and, secondly, the reduction in the price of smartphones due to competitive pricing of devices (Kende, 2015). Poushter (2016) feels that the proper adaptation and use of mobile technology is currently the crucial factor in human progress. This leads to Sharples, Sánchez, Milrad, and Vavoula (2009) asking why people take to using mobile technologies. The following listed benefits of mobile technology use go a long way in answering Sharples et al. (2009) question:

- It is easy to use and requires only one hand engagement (Rashevska \& Tkachuk, 2018).

- Functionalities are rich and devices have many sensors, therefore many more abilities (Casey \& Babu, 2016).

- It is smaller and ubiquitous (Bagot, Matthews, Mason et al., 2018).

- It does not require lengthy boot up and shut down (Paily, 2016).

- It facilitates easy access to applications, like checking e-mails and shopping online (Casey \& Babu, 2016).

- A very suitable personal device that keeps track of meetings etc. and thus helps one to organise his/her life (Mabila et al., 2017).

The literature further suggests that learners are embracing mobile devices, so much so that they prefer group facilitated learning through social media platforms like Facebook and WhatsApp (Aventurier, 2014; Blodgett, 2017; Kasemsap, 2017). Rodriguez and Igartua (2018a) strongly agree and note that social group education thrives due to quick response times and easy sharing of resources (Blodgett, 2017). Other scholars suggested that learners prefer e-mail as a method of communication with their educator (Krish \& Salman, 2018; Savić, 2018). This preference was as a result of its formality, record being kept of conversations and ability to ask more detailed and comprehensive questions (Krish \& Salman, 2018).

Despite the listed benefits, users need to have some knowledge of safety and security guidelines when using mobile devices (Chew, Cheng, \& Chen, 2018; Collins \& Halverson, 2018; Kluzer, 2015). Several precautions have been listed to safeguard mobile devices and their owners (Chew et al., 2018; Collins \& Halverson, 2018; Kluzer, 2015).

Further to these selected highlights, the selected papers' examination for relevant Mobile digital literacy skills for the use of mobile technologies, led to the additional identification and classing according to the categories identified in the a priory framework selected in Section 3. The ordered skills are presented in Table 4 with the literature that supports it, and the dimensions and categories used to synthesize this conceptualization of Mobile Digital Literacy skills

Table 4. Identified and classed Mobile Digital Literacy skills as obtained from the literature study

\begin{tabular}{l|lll}
\hline $\begin{array}{l}\text { Dimensions: } \\
\text { Digital } \\
\text { Literacy Model }\end{array}$ & $\begin{array}{l}\text { Category of } \\
\text { Digital literacy } \\
\text { skills (Ng, 2012) }\end{array}$ & $\begin{array}{l}\text { Mobile digital literacy skills for } \\
\text { the use of mobile technologies }\end{array}$ & Support from Literature \\
\hline $\begin{array}{l}\text { Technical } \\
\text { dimension }\end{array}$ & Operational literacy & $\begin{array}{l}\text { Getting started with a mobile } \\
\text { device } \\
\text { Personalization of one's device }\end{array}$ & $\begin{array}{l}\text { (Martin, 2018) } \\
\text { (Kelly \& Minges, 2012) } \\
\end{array}$ \\
& $\begin{array}{l}\text { Underpinnings - basic skills to } \\
\text { operate a device }\end{array}$ & $\begin{array}{l}\text { 2013); (Kelly \& Minges, 2012); (Pan, } \\
\text { 2012); (Brown \& Mbati, 2015); (Caudill, }\end{array}$ \\
& & 2007) \\
\hline
\end{tabular}




\begin{tabular}{|c|c|c|c|}
\hline $\begin{array}{l}\text { Dimensions: } \\
\text { Digital } \\
\text { Literacy Model } \\
\end{array}$ & $\begin{array}{l}\text { Category of } \\
\text { Digital literacy } \\
\text { skills }(\mathrm{Ng}, 2012) \\
\end{array}$ & $\begin{array}{l}\text { Mobile digital literacy skills for } \\
\text { the use of mobile technologies }\end{array}$ & Support from Literature \\
\hline $\begin{array}{l}\text { Social- } \\
\text { emotional } \\
\text { dimension }\end{array}$ & $\begin{array}{l}\text { Social-emotional } \\
\text { literacy } \\
\text { Social networking } \\
\text { functional literacy }\end{array}$ & $\begin{array}{l}\text { Understanding mobile hardware } \\
\text { operation, affordances and } \\
\text { specifications of a device } \\
\text { Using basic functionalities on a } \\
\text { mobile device to organize one's } \\
\text { life } \\
\text { Adaptability } \\
\text { Navigation - use of fingers to } \\
\text { navigate } \\
\text { Application management } \\
\text { Securing one's device and its } \\
\text { contents } \\
\text { Understanding the internet } \\
\text { platform } \\
\text { Use the internet to search } \\
\text { information } \\
\text { Use of social networks for } \\
\text { collaborative learning and } \\
\text { teamwork } \\
\text { Being part of online groups } \\
\text { Sharing and storing of } \\
\text { information -cloud computing } \\
\text { Using social networks for } \\
\text { professional growth and } \\
\text { collaboration } \\
\text { Communication }\end{array}$ & $\begin{array}{l}\text { (Kelly \& Minges, 2012); (Brown } \\
\text { \& Mbati, 2015); (Caudill, 2007); (Martin, } \\
\text { 2018) } \\
\text { (Ventimiglia \& Pullman, 2016); (Kelly } \\
\text { \& Minges, 2012); (Sharon, 2003); } \\
\text { (Rashevska \& Tkachuk, 2018) } \\
\text { (Brown \& Mbati, 2015) } \\
\text { (Kelly \& Minges, 2012); (Pan, 2012); } \\
\text { (Bagot et al., 2018) } \\
\text { (Casey \& Babu, 2016); (Kelly \& Minges, } \\
\text { 2012); (Hausknecht \& Kaufman, 2018) } \\
\text { (Kluzer, 2015); (Paasch \& Duchene, } \\
\text { 2012); (Hicks \& Turner, 2013); (Voogt, } \\
\text { Erstad, Dede, \& Mishra, 2013) } \\
\text { (Clark et al., 2017); (Saxena, Gupta, } \\
\text { Mehrotra et al., 2017) } \\
\text { (Chipangura, 2016); (Qadir, Gordon, Tan } \\
\text { et al., 2018) } \\
\text { (Rodriguez \& Igartua, 2018b); (Zhang, } \\
\text { 2018) } \\
\text { (Krish \& Salman, 2018) } \\
\text { (Mitrovic, 2017) } \\
\text { (Nagel \& Verster, 2012); (Aventurier, } \\
\text { 2014; Mayisela, 2013); (Bansal \& Joshi, } \\
\text { 2014); (Rodriguez \& Igartua, 2018a) } \\
\text { (Nagel \& Verster, 2012); (Chipangura, } \\
\text { 2016); (Harper, 2003; Jones \& Flannigan, } \\
\text { 2006); (Kelly \& Minges, 2012); } \\
\text { (Dahlstrom, Walker, \& Dziuban, 2013); } \\
\text { (Martin, 2018) }\end{array}$ \\
\hline & $\begin{array}{l}\text { Online etiquette } \\
\text { Literacy } \\
\text { Cyber Safety } \\
\text { Literacy }\end{array}$ & $\begin{array}{l}\text { Conduct and demeanour over the } \\
\text { internet } \\
\text { Being safe in the online world }\end{array}$ & $\begin{array}{l}\text { (Voogt et al., 2013); (Dhir, Kaur, Jere, } \\
\text { \& Albidewi, 2012); (Chew et al., 2018) } \\
\text { (Kluzer, 2015); (Chew et al., 2018) }\end{array}$ \\
\hline $\begin{array}{l}\text { Cognitive } \\
\text { dimension }\end{array}$ & $\begin{array}{l}\text { Reproduction } \\
\text { Literacy }\end{array}$ & $\begin{array}{l}\text { Dealing with graphics, video and } \\
\text { animation } \\
\text { Content recreation } \\
\text { Word processing and electronic } \\
\text { spreadsheets }\end{array}$ & $\begin{array}{l}\text { (Kelly \& Minges, 2012); (Dhir et al., } \\
\text { 2012) } \\
\text { (Dhir et al., 2012) } \\
\text { (Martin, 2018) }\end{array}$ \\
\hline & Branching Literacy & $\begin{array}{l}\text { Multidimensional skills at } \\
\text { sourcing information } \\
\text { Developing a connection between } \\
\text { different forms of information } \\
\text { Having visual and media } \\
\text { knowledge }\end{array}$ & $\begin{array}{l}\text { (Chipangura, 2016) } \\
\text { (Mabila et al., 2017); (Russell, Rawson, } \\
\text { Freestone et al., 2018) } \\
\text { (Dhir et al., 2012) }\end{array}$ \\
\hline $\begin{array}{l}\text { Literacy for all } \\
\text { dimensions }\end{array}$ & $\begin{array}{l}\text { Information } \\
\text { Literacy } \\
\text { Critical Literacy } \\
\text { and other literacies } \\
\text { like financial } \\
\text { literacy and work } \\
\text { around literacy }\end{array}$ & $\begin{array}{l}\text { Background knowledge in } \\
\text { acquiring information }\end{array}$ & $\begin{array}{l}\text { (Mabila et al., 2017); (Russell et al., } \\
\text { 2018) } \\
\text { (Van Biljon \& Kotzé, 2007); (Astill, } \\
\text { 2017); (Supachayanont, 2011) }\end{array}$ \\
\hline
\end{tabular}


The table 4 provides an initial conceptualization of Mobile digital literacy skills for the use of mobile technology as identified from literature, framed by the a priory framework constituted by the digital literacy model of $\mathrm{Ng}$ (2013).

\section{CONCLUSION}

In this paper, a conceptualization of mobile digital literacy skills towards eventually enabling the articulation of the mobile digital literacy skills needed by educators using mobile technologies in formal education is resented and the research question (What constitutes mobile digital literacy skills for educators in formal education?) answered (Table 4). The authors paper exapted the 'best-fit' framework synthesis of Carroll et al. (2013) from the health domain, towards conceptualizing mobile digital literacy skills for educators when embarking on using mobile technology in their classroom practices. Table 4 suggests a conceptualization of mobile digital literacy skills needed by an educator. This will, going forward, in its turn, be used as an updated a priory framework to explore a nuanced conceptualization framed specifically by the activities of the educator within their classroom practice.

As it currently stands however, the conceptualization can serve as a Meta level guide for future training programmers designed for educators. Educators and experts developing courses for ICT in schools may also benefit from this study, as they seek to enhance their skills to heighten the success of implementing mobile technologies in formal education. This study further provide educators with a list of skills to assess themselves in terms of implementing mobile technology in the classroom.

\section{REFERENCES}

Astill, J. (2017). Beefing up mobile-phone and internet penetration in Africa. The Economist.

Aventurier, P. (2014). Academic social networks: challenges and opportunities. Paper presented at the 7th UNICA Scholarly Communication Seminar.

Bagot, K., Matthews, S., Mason, M., Squeglia, L., Fowler, J., Gray, K., . . . Godino, J. (2018). Current, Future and Potential Use of Mobile and Wearable Technologies and Social Media Data in the ABCD Study to Increase Understanding of Contributors to Child Health. Developmental cognitive neuroscience.

Bansal, T., \& Joshi, D. (2014). A study of students experiences of WhatsApp mobile learning. Global Journal of Human-Social Science Research.

Bartikowski, B., Laroche, M., Jamal, A., \& Yang, Z. (2018). The type-of-internet-access digital divide and the well-being of ethnic minority and majority consumers: A multi-country investigation. Journal of Business Research, 82, 373-380.

Blodgett, J. (2017). Taking the class out of the classroom: Libraries, literacy, and service learning The Experiential Library (pp. 43-52): Elsevier.

Brown, H., \& Mbati, L. S. (2015). Mobile Learning: Moving Past the Myths and Embracing the Opportunities. 16(2), $115-115$.

Carroll, C., Booth, A., Leaviss, J., \& Rick, J. (2013). "Best fit" framework synthesis: refining the method. BMC medical research methodology, 13(1), 37. doi:10.1186/1471-2288-13-37

Casey, M., \& Babu, A. (2016). Game of Phones: Deloitte's Mobile Consumer Survey. The Africa cut 2015/2016. . Retrieved from https://www2.deloitte.com/content/dam/Deloitte/za/Documents/technology-mediatelecommunications/ZA_Deloitte-Mobile-consumer-survey-Africa-300816.pdf

Caudill, J. G. (2007). The Growth of m-Learning and the Growth of Mobile Computing: Parallel developments. International Review of Research in Open and Distance Learning, 8(2).

Chang, C.-Y., \& Hwang, G.-J. (2018). Trends of mobile technology-enhanced medical education: a review of journal publications from 1998 to 2016. Int. J. Mobile Learning and Organisation, 12(4), 373.

Chew, S. W., Cheng, I.-L., \& Chen, N.-S. (2018). Exploring challenges faced by different stakeholders while implementing educational technology in classrooms through expert interviews. Journal of Computers in Education, 5(2), 175-197.

Chipangura, B. (2016). A Framework for providing mobile centric services to students at higher education institutions: The case of open distance learning.

Clark, M., Coward, C., Rothschild, C., Reynal, 1. d., \& Richter, B. (2017, 2017). Towards a Mobile Information Literacy framework: Rethinking Information Literacy in a Mobile Era. 
Collins, A., \& Halverson, R. (2018). Rethinking education in the age of technology: The digital revolution and schooling in America: Teachers College Press.

Dahlstrom, E., Walker, J., \& Dziuban, C. (2013). ECAR study of undergraduate students and information technology. Retrieved from www.educause.edu/ecar:

Dhir, A., Kaur, P., Jere, N., \& Albidewi, I. A. (2012). Understanding mobile phone battery-human interaction for developing world a perspective of feature phone users in africa. Paper presented at the Future Internet Communications (BCFIC), 2012 2nd Baltic Congress on.

Eshet-Alkalai, Y. (2004). Digital literacy: A conceptual framework for survival skills in the digital era. Journal of Educational Multimedia and Hypermedia, 13(1), 93-106.

Eshet-alkalai, Y., \& Chajut, E. (2009). Changes Over Time in Digital Literacy. 12(6).

Ferrari, A. (2008). Digital Competence in Practice : An Analysis of Frameworks. Retrieved from www.jrc.ec.europa.eu:

Finn-Stevenson, M. (2018). Schools of the 21 st century: Linking child care and education: Routledge.

Gilster, P. (1997). Digital literacy. The thinking and survival skills new users need to make the internet personally and professionally meaningful.

Grant, M. J., \& Booth, A. (2009). A typology of reviews: an analysis of 14 review types and associated methodologies. Health Information \& Libraries Journal, 26(2), 91-108.

Hansen, J. J. (2018). Digital literacy-cognitive strategies, genre skills and situated practice Designing for Learning in a Networked World (pp. 138-157): Routledge.

Harper, V. (2003). The digital divide (DD): A reconceptualization. Association for the Advancement of Computing in Education (AACE), 11(1), 96-103.

Hausknecht, S., \& Kaufman, D. (2018). Increasing digital literacy skills of older adults through a digital storytelling project-based course. Paper presented at the EdMedia+ Innovate Learning.

Hicks, T., \& Turner, K. H. (2013). No longer a luxury: Digital literacy can't wait. English Journal, 6, 58-65.

ITU. (2018). Achieving universal and affordable Internet in the least developed countries (9789261254513). Retrieved from https://www.itu.int/en/ITU-D/LDCs/Pages/ICTs-for-SDGs-in-LDCs-Report.aspx:

Jere, N. R., Thinyane, M., Boikhutso, T., \& Ndlovu, N. (2013). An assessment of ICT challenges in rural areas: ICT experts vs rural users views: a case of the Siyakhula Living Lab. Paper presented the Proceedings of the South African Institute for Computer Scientists and Information Technologists Conference.

Jisc. (2015). Digital students are different. $\quad$ Retrieved https://drive.google.com/file/d/\%0A0B4y3qNoTbFdYd0ttdEx1STVyeDRFOGdvMVhkeWhMdjZYcVBR/view?pli1/4 1(

Jones, B. R., \& Flannigan, S. (2006). Connecting the Digital Dots : Literacy of the 21st Century. Workforce, 29(2), 8-10. doi:Article

Kasemsap, K. (2017). Digital storytelling and digital literacy: Advanced issues and prospects Deconstructing the Education-Industrial Complex in the Digital Age (pp. 151-171): IGI Global.

Kelly, T., \& Minges, M. (2012). Maximizing Mobile.

Kende, M. (2015). Global Internet Report 2015: Mobile Evolution and Development of the Internet: Internet Society.

Kluzer, S. (2015). Guidelines on the adoption. 1-28.

Krish, P., \& Salman, Q. (2018). Politeness in Email Communication Among Arab Postgraduate Students in a Malaysian Public University. e-Bangi, 11(2).

Lankshear, C., \& Knobel, M. (2008). Concepts, Policies and Practices (Vol. 30, pp. 29-29): Peter Lang.

Mabila, J., Biljon, J. V., \& Herselman, M. (2017). A sustainability framework for mobile technology integration in schools : The case of resource- constrained environments in South Africa. The Journal of Community Informatics, 13(2), 59-86.

Markauskaite, L. (2007). Exploring the structure of trainee teachers' ICT literacy: the main components of, and relationships between, general cognitive and technical capabilities. Educational Technology Research and Development, 55(6), 547-572.

Martin, J. P. (2018). Skills for the 21st century: Findings and policy lessons from the OECD survey of adult skills. Retrieved from

Mayisela, T. (2013). The potential use of mobile technology: enhancing accessibility and communication in a blended learning course. South African Journal of Education, 33(1), 1-18.

Mitrovic, Z. (2017). The impact of cloud computing on the role of an IT department: a case study of a higher education institution in the Western Cape. Cape Peninsula University of Technology.

Mushi, R., Jafari, S., \& Ennis, A. (2018). Measuring Mobile Phone Technology Adoption in SMEs: Analysis of Metrics Technology Adoption and Social Issues: Concepts, Methodologies, Tools, and Applications (pp. 1546-1557): IGI Global.

Nagel, L., \& Verster, M. (2012). A student-grown Facebook group in an architecture class: Seed or weed.

Ng, W. (2012). Can we teach digital natives digital literacy? Computers and Education, 59(3), 1065-1078. doi:10.1016/j.compedu.2012.04.016

$\mathrm{Ng}$, W. (2013). Conceptualising mLearning Literacy. International Journal of Mobile and Blended Learning, 5(1), 1-20. doi:10.4018/jmbl.2013010101 
Paasch, C., \& Duchene, F. (2012). Exploring Mobile / WiFi Handover with Multipath TCP Categories and Subject Descriptors. Cellular Networks: Operations, Challenges, and Future Design (CellNet), 1-6. doi:10.1145/2342468.2342476

Paily, M. U. (2016). [Information and communication technology].

Pan, Y. (2012). Portable tablet computing device with a low power operation mode as a media player: Google Patents.

Parry, R., Eikhof, D. R., Barnes, S.-A., \& Kispeter, E. (2018). Development, supply, deployment, demand: Balancing the museum digital skills ecosystem. First findings of the 'One by One'national digital literacy project.

Poushter, J. (2016). Smartphone Ownership and Internet Usage Continues to Climb in Emerging Economies. Retrieved from

Qadir, J., Gordon, S., Tan, J., Chiaraviglio, L., Wu, J., \& Zhang, W. (2018). A Sustainable Connectivity Model of the Internet Access Technologies in Rural and Low-Income Areas. Paper presented at the Smart Grid and Innovative Frontiers in Telecommunications: Third International Conference, SmartGIFT 2018, Auckland, New Zealand, April 23-24, 2018, Proceedings.

Rashevska, N., \& Tkachuk, V. (2018). Technological conditions of mobile learning in high school. arXiv preprint arXiv:1808.01989.

Rodriguez, -. d.-D. I., \& Igartua, J.-J. (2018a). Skills of digital literacy to address the risks of interactive communication Information and Technology Literacy: Concepts, Methodologies, Tools, and Applications (pp. 621-632): IGI Global.

Rodriguez, d.-D. I., \& Igartua, J.-J. (2018b). Skills of digital literacy to address the risks of interactive communication Information and Technology Literacy: Concepts, Methodologies, Tools, and Applications (pp. 621-632): IGI Global.

Russell, F., Rawson, C., Freestone, C., Currie, M., \& Kelly, B. (2018). Parallel Lines: A Mixed Methods Impact Analysis of Co-Curricular Digital Literacy Online Modules on Student Results in First Year Nursing. College \& Research Libraries.

Sadaf, A., \& Johnson, B. L. (2017). Teachers' Beliefs About Integrating Digital Literacy Into Classroom Practice: An Investigation Based on the Theory of Planned Behavior. Journal of Digital Learning in Teacher Education, 33(4), 129-137.

Savić, M. (2018). Lecturer perceptions of im/politeness and in/appropriateness in student e-mail requests: A Norwegian perspective. Journal of Pragmatics, 124, 52-72.

Saxena, P., Gupta, S. K., Mehrotra, D., Kamthan, S., Sabir, H., Katiyar, P., \& Prasad, S. S. (2017). Assessment of digital literacy and use of smart phones among Central Indian dental students. Journal of Oral Biology and Craniofacial Research.

Schreuers, K., Quan-Haase, A., \& Martin, K. (2017). Problematizing the digital literacy paradox in the context of older adults' ICT use: Aging, media discourse, and self-determination. Canadian Journal of Communication, 42(2), 1.

Sharon, M. (2003). an Introduction To Mobile Technologies and services. Machine Learning, 2010(June), 9128-9128.

Sharples, M., Sánchez, I. A., Milrad, M., \& Vavoula, G. (2009). Mobile learning Small devices, big issues (pp. 20-20).

Supachayanont, A. (2011). Workaround as a craft skill of the computerised paper production process. University of St Andrews.

Valk, J.-H., Rashid, A. T., \& Elder, L. (2010). Using mobile phones to improve educational outcomes: An analysis of evidence from Asia (Vol. 11, pp. 117-140).

Van Biljon, J., \& Kotzé, P. (2007). Modelling the factors that influence mobile phone adoption. Paper presented at the Proceedings of the 2007 annual research conference of the South African institute of computer scientists and information technologists on IT research in developing countries.

Van Biljon, J., \& Renaud, K. (2017). Harnessing both Information and Knowledge Visualisation to Represent a Community of Practice: Depicting the South African ICT4D Researcher Community.

Ventimiglia, P., \& Pullman, G. (2016). From Written to Digital: The New Literacy. Educause Review, 51(2).

Voogt, J., Erstad, O., Dede, C., \& Mishra, P. (2013). Challenges to learning and schooling in the digital networked world of the 21st century. Journal of Computer Assisted Learning, 29(5), 403-413. doi:10.1111/jcal.12029

Walls, E. (2017). The perceived relation between ICTs and social good. University of Southampton.

Yu, T.-K., Lin, M.-L., \& Liao, Y.-K. (2017). Understanding factors influencing information communication technology adoption behavior: The moderators of information literacy and digital skills. Computers in Human Behavior, 71, 196208. doi:http://dx.doi.org/10.1016/j.chb.2017.02.005

Zapata, G. C. (2018). The Role of Digital, Learning by Design Instructional Materials in the Development of Spanish Heritage Learners' Literacy Skills Multiliteracies Pedagogy and Language Learning (pp. 67-106): Springer.

Zhang, L. (2018). Automatic Traffic Scheduling for Internet Connectivity Failures.

Zheng, B., Yim, S., \& Warschauer, M. (2018). Social media in the writing classroom and beyond. The TESOL Encyclopedia of English Language Teaching, 1-5. 